\title{
Norm Detachment: Unwillingness of Millennials to Negotiate
}

\author{
Daniel H. Boylan \\ Purdue University \\ Josh Gallone \\ Widener University \\ Bianca Beerman \\ Purdue University
}

Although millennials seem aware of the need for negotiating, salaries paid to starting employees do not always reflect this. It is much more likely for a job candidate to accept an offer for employment without negotiation than it is for a job candidate to bargain for a higher salary. At one point in time bargaining for a higher salary was commonplace. However, due to unknown circumstances millennials seem to be unwilling to negotiate. Our results show that millennials do not negotiate during times viewed as appropriate and times where negotiating could reap substantial benefit. This raises certain questions as to why that may be. We have looked at numerous articles about the behavior of millennials and their skills in negotiating. The results of these articles showed that millennials may not negotiate due to embarrassment or lack of care, but we also found that millennials can be taught how to negotiate. Our research also shows that millennials tend to do things on impulse or for instant gratification.

Keywords: millennial, negotiation, self-interest, consumer finance, reward theory

\section{INTRODUCTION}

The millennial generation has its own set of views and beliefs on the art of negotiation (McGinnis \& $\mathrm{Ng}$, 2016; Stein, 2013). Research shows millennials do not negotiate when it is proper, and they could reap far greater benefits if they were to negotiate. The research gap we came across is an expansive dilemma to look at, so researchers are only focusing on age as a qualifying quality in this paper. Different reasons one would be naturally more inclined to negotiate include personality, race, gender, etc. A big problem with the new millennial generation is fewer people are negotiating and are missing greater benefits they could have taken part in just by asking. Millennials are more ambitious than previous generations when it comes to starting up and owning their own business (Liu, Serapio, Zhu, \& Cavusgil, 2019; Myers, \& Sadaghiani, 2010). A 2011 study by the research network Affluence Collaborative found almost $40 \%$ of millennials "have started a business or expect to do so," making their entrepreneurship rate $10 \%$ higher than the general population (Colao, 2012).

Many Millennials feel uncomfortable negotiating purchases and salaries. These are some questions to consider: (1) Have you been involved in a salary negotiation? (2) If yes, when and how did the negotiation 
take place? (3) Did you accept or reject the position and why? (4) Did you feel you were prepared to negotiate? The usual answer to the first question is "no," and about two or three students signal they have negotiated salary at least once (Levine, 2011). According to Lyang (2009) "Most students have accepted the position offered, and all report they did not feel prepared to discuss salary" (Lyang, 2009). This research is important because the percentage of millennial employees in this country is growing. They need to start negotiating for better salaries and benefits before losing the opportunity for these advantages. After a teacher gave a class in negotiation, she reported this finding: "Several alumni have returned to campus after becoming employed and have shared their successful negotiations. Many of my students have increased their beginning salaries by thousands of dollars, and others by as much as $\$ 10,000$, by using the information from the salary negotiating activity. What began as a 20-minute discussion in one class is now permanently integrated into the interview exercise and takes three 75-minute class periods" (Layng, 2009). Their class in negotiating was such a success the students who returned shared their success stories, and they started with a salary far greater than they would have had if they had not negotiated.

Why are millennials unwilling to negotiate? This is a significant issue because negotiation is how employees increase their salary and reduce prices on larger items such as cars. Generations before millennials negotiated with ease and would fight to get their way, but millennials do not mimic this attitude. Only 37 percent of millennials have ever asked for a raise, according to PayScale (Lockert, 2107). The main question is why has it changed, and what is causing this generation to be unwilling to negotiate when it could better themselves. "Millennials have been told they'll get more career rewards if they wait patiently. They're offered a position with low pay and told better pay will come later if they work hard and stay put" (Deal, 2017). For this reason, millennials may not prefer negotiating a starting salary. "In an exclusive survey of 548 millennials in the U.S., $82 \%$ said they did not negotiate their first salaries because they either didn't feel comfortable (38\%) or didn't know they could do so (44\%) (Goudreau, 2014).

What causes the lack of interest for millennials to negotiate? Several factors exist including embarrassment, lack of knowledge, or a lack of need. Research shows millennials react to impulse or instant comfort. Millennials may have a fear of job loss if appearing too aggressive towards an employer. "Millennials need to realize many employers expect negotiation. Not only, but your employer may sense you as more confident if you negotiate, according to a study by NerdWallet" (Lockert, 2017).

TABLE 1 NUMBER OF ARTICLES ON PFW HELMKE LIBRARIES

\begin{tabular}{lc}
\hline Keyword(s) & Number of articles \\
\hline millennial & 41,234 \\
\hline millennial, negotiation & 2,093 \\
\hline millennial, negotiation, self-interest & 196 \\
\hline
\end{tabular}

The Table above shows the results of a search on the Purdue University, Fort Wayne Helmke Libraries. There were over 41,000 peer-reviewed articles about "millennials." Roughly 2,700 peer-reviewed articles were found with "millennials" and "negotiation." 196 articles were using "millennials," "negotiation," and "self-interest." Of these 196 articles, none of them related to the topic studied by our research. This shows the need for this study.

Researchers of this study believe that it is important to understand whether Millennials are unwilling to negotiate their salaries. Researchers want to understand this to improve Millennial's knowledge and readiness to negotiate. If Millennials can be taught to negotiate their salaries appropriately, they will reap great benefits in their future careers.

Researchers organized the balance of this work into the following four sections. First, there is a literature review looking at prior literature that informs this study. The next section includes methodology, 
including both the research question and experiment design. The third section includes the research findings. Finally, the research ends with conclusions, including limitations and future research.

\section{LITERATURE REVIEW}

Schwartz (2014) researched why people do not act in their own best interest. While attending the World Economic Forum researchers asked people from each table to figure out "what do you see as the world's biggest challenges?" They found people created problems, but no one knew how to solve these problems. The conclusion was people decide for "now" and do not think about future consequences. He later explains our brains are programmed to react to signs of immediate threat and thrive for instant indulgence. The solution suggested by Schwartz is to rely on the prefrontal cortex in the brain this part helps us imagine the future so we do not take action that could later cause great consequences. It is the fact people do not think about the future that leads to many avoidable problems. They may try to avoid embarrassment today without even thinking about the problems it may bring in the future (Schwartz, 2014).

Yannessa, Dunn, Yansick, and Jordan (2017) examined the purchase of condoms. This study looks into why adolescents do not buy condoms even though they know it is in their best interest. Researchers looked at what embarrassed adolescents when it comes to condoms. One situation presents a negotiation between partners when stopping and asking to use a condom. Another is the purchase, including the location, of a condom. People prefer to risk not using a condom rather than enduring embarrassment talking to their partner or talking to a store clerk. People rationalize the now instead of thinking about what future consequences could come because of embarrassment (Yannessa, Dunn, Yansick, \& Jordan, 2017).

Research conducted by Layng (2009) is a qualitative study documenting experiences as a consultant and the class she held teaching students how to negotiate. She said, "the art of negotiation is understood by few people or regularly used, and yet most people negotiate several times a day" (Layng, 2009; Groth, 2001). She discusses how some schools offer classes and seminars, teaching students how to negotiate. Layng asks right off the bat in her class if they have been in a salary negotiation since it's the most common item people should negotiate. One of the concerns found with students is they do not feel prepared when it comes to negotiating the salary because most do not know their self-worth or the salary range of the position. This article discusses two different types of negotiation. The first is a hard offer where the company offers a job to a candidate, then asks the candidate their salary requirements. The second is a soft negotiation, this is when the interviewer low balls the candidate for salary. The knowledge the students gained from this class helped them increase their starting salary by thousands of dollars (McGinnis Johnson $\& \mathrm{Ng}, 2016)$.

The unwillingness of Millennials to negotiate stems from multiple factors. From embarrassing negotiation to wanting instant gratification with no care about future consequences and last the lack of knowledge on negotiation (Khazan, 2017). Layng says in her paper "As a consultant and a teacher, I find that bringing real-life situations into my classroom better prepares my students for the business world" (Layng, 2009). The studies done show teaching millennials how to negotiate would decrease the likelihood they would be unwilling to negotiate.

The millennial generation is gearing marketers to learn how to advertise to attract this generation. Millennials, the most ethnically and racially diverse generation in United States history, are a global generation and targeted by marketers because of their significant buying power (United States. Congress. Joint Economic Committee, 2016). Millennial spending in the United States is significant, as 80 million millennials spend over $\$ 600$ billion a year. This group represents $28 \%$ of all daily per-person consumer spending. This volume is expected to grow as millennials should account for $35 \%$ of spending by 2030 . No matter how you define it, millennial spending is important (Kestenbaum, 2017). Social media helps marketers reach this generation like never before (Pate \& Adams, 2013). Jacobsen and Forste (2010) suggest Millennials are not only technologically savvy but are also excellent at multitasking and visiting with friends on multiple social networks (Jones, Johnson-Yale, Millermaier, \& Perez, 2009; Sweeney, 2006). Individuals use social media to purchase products. Often the related consumer reviews play a part in that purchase. Over $60 \%$ of people age $18-24$ would try a product suggested by a YouTuber, and $69 \%$ of 
Millennials have admitted to experiencing "fear of missing out" or "FOMO" (Forer, 2017). Retailers use consumers' friends on Facebook by posting their recent purchases in hopes of persuading their "friends" to purchase the same or similar items (Daboll, 2012; Pöyry, Parvinen, \& Malmivaara, 2013). The power of the Internet as a shopping tool can be shown by the total number of users in North America ( $78 \%$ of the population) (Bureau of Labor Statistics, 2017). Facebook now has up and running its marketplace to give users alternatives of lower-priced items others are trying to get rid of. Facebook has such a strong presence in the social media platform which allows users to easily access a selling environment with many followers to view their products.

\section{METHODOLOGY}

This research focuses on why millennials are unwilling to negotiate. The research further showed why millennials are unwilling to or do not want to negotiate. The reasoning for the unwillingness to negotiate is from embarrassment about the act of negotiating. Also, there is a lack of both wanting to negotiate and comfort in their skills when it comes to negotiating. Teaching them how to negotiate would decrease the number of millennials unwilling to negotiate. The independent variable is negotiating itself. The dependent variable is why the millennials are refusing or are unwilling to negotiate.

\section{Participants}

The population used for this data came from various classes across Widener University's campus from freshmen to seniors, with students from Widener's business school making up much of the data. Researchers chose this population to get a strong sample from a various number of students with different majors to see why there is a lack of millennials wanting to negotiate. The research found on this specific population proves millennials do not want to negotiate. Similar to other millennials, the students of Widener said they have a lack of knowledge on how to negotiate. They felt if teachers included negotiation in the classroom they would feel more confident in negotiating. All this data confirmed the research on millennials being unwilling or not wanting to negotiate.

TABLE 2

THE CLASS STANDING OF RESPONDENTS SURVEYED

\begin{tabular}{llc}
\hline Class Standing & $\mathrm{n}$ & $\%$ \\
\hline Freshman & 17 & 15 \\
Sophomore & 36 & 32 \\
Junior & 16 & 15 \\
Senior & 41 & 37 \\
Refuse to answer & 1 & 1 \\
\hline Total & 111 & 100 \\
\hline
\end{tabular}

From the Table above, one can see the majority are seniors. Seniors comprised the largest group in the sample with 41 students. It is in their self-interest to gain negotiation skills before entering the work world after graduation. Having the skills to negotiate will assist in helping them get better starting salaries. Sophomores have the next highest participation level at 36 students followed by only 17 freshmen and 16 juniors. This is a result of the vested interest seniors have in the topic as they are applying for jobs and negotiating salaries. As far as sophomores go with the second-highest percentage, this can be a direct correlation to students involved with internships or co-op programs involving their careers. With freshmen, the number is expected to be lower as they are more worried about starting their college career and not so focused on negotiation quite yet.

Most of the students who responded to the questionnaire were White, Male, Accounting Major, and around the age of twenty years old. Further, the information gathered from the questionnaires and displayed in the table was seventy-seven of the students scored above fifty to be in the bracket defining them as ones 
who know how to negotiate. Also, the students who answered the seventeenth question on the questionnaire answered lack of knowledge or other. The other response usually had to do with not wanting to lose a job because of salary negotiation and the other reason was students felt they were not put into a situation where they needed to negotiate. Lastly, nineteen students scored between twenty and fifty which shows they know about negotiating, but they need improvement in their skills.

\section{Procedures}

Researchers reviewed several questionnaires related to millennials and negotiation from online sources. These questionnaires included: researcher's added demographic information related to age, sex, ethnic background, major, and location to the questionnaire so further analysis could be completed if results warranted.

The questionnaire selected was one previously peer-reviewed and published on negotiation. This questionnaire involved several questions the researchers felt were relevant for this study. The questionnaire included several negotiation questions related to the process, expected outcomes, negotiator skillset, and feeling to negotiations (Cook, 2007). Since this author had published this questionnaire several times researchers felt the author would have updated questions based on feedback from the author's work. The questionnaire included sixteen questions using a Likert Scale using the letters "A," "B," "C," "D," and "E" to rank responses. One additional question was included that was "open-ended" so respondents could add any comments that may not fit the Likert Scale. Researchers also liked that the questionnaire used a Likert Scale so results could be quantified, and descriptive statistics could be easily applied. At the end of the questionnaire, researchers included standard demographics questions so the analysis could include subgroups if applicable.

Research assistants administered surveys at a medium-sized East Coast private university in various classes in the business school. The entire sample for this study was millennials. If a person falling outside the millennial definition took the survey, researchers removed that questionnaire from the sample. Researchers used Investopedia to determine the year from which the millennial generation was spanned. Millennial is the name given to the generation born between 1982 and 2004 (Radcliffe 2018). This meant the millennials would be between the ages of 14 and 36. Four questions were taken out of the questionnaire so an open-ended question could be added, and so the time for the students to take this questionnaire in class stayed within a reasonable time so the professor did not lose valuable class time.

\section{Statistics}

First, all the data came from students surveyed on campus. Researchers imported data into Excel where advanced analytics were applied. After totaling all the questionnaires, another table was put in place to see what all the different scores were, and how they were placed on the scale the questionnaire contained. The original questionnaire had a scoring system that goes as follows: 70-100 was a good negotiator with a good understanding, 40-69 was an average negotiator who could use some improvement, and 1-39 which meant development in negotiating skills were required. Since researchers removed four questions, they reduced the scores by 20 points for all three of the different scoring brackets. Once all the scores were put into the three categories the next steps were taken to continue with the findings.

\section{FINDINGS}

This section shows the results of the research. These findings were completed by first reviewing and finding the key items in the data collection process. The research looked at college students, their knowledge of negotiations, and their willingness to engage in salary negotiations. Next, the data was analyzed from a descriptive statistics standpoint using advanced analytics in the program Excel. Sample distribution is shown below in Figure 1. Researchers analyzed the questions from the questionnaire given to the participants. 


\section{FIGURE 1 \\ HISTOGRAM SHOWING THE NORMAL DISTRIBUTION OF THE RESEARCH}

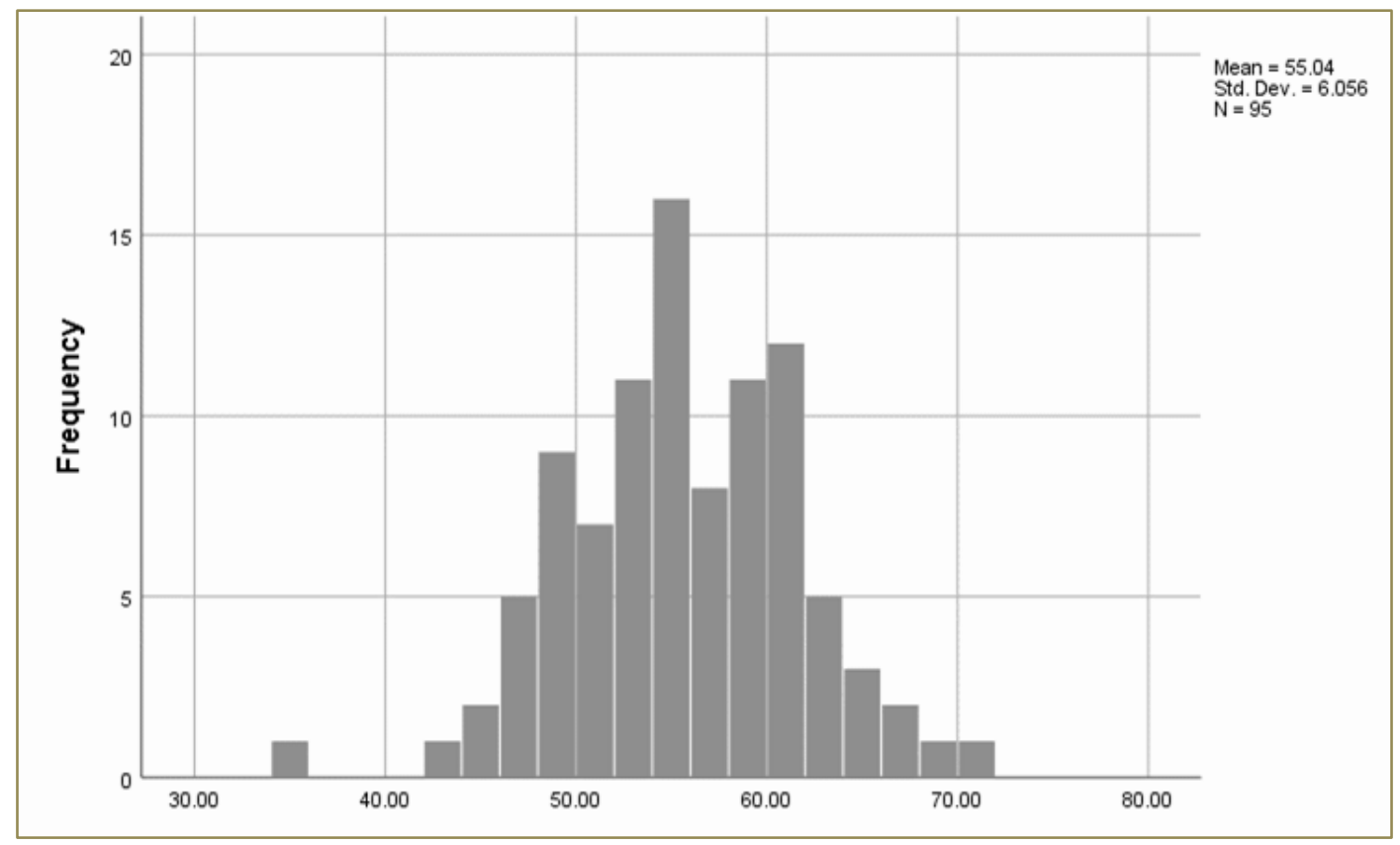

Figure 1 shows the normal distribution of the sample. It shows the results of the questionnaire results. It can be seen the mean score is 55.04. Researchers adjusted scoring the questionnaire by reducing the categories by 20 points. Because of the adjustment the mean score over the threshold of being considered a good negotiator with a good understanding of how to negotiate.

One question the researchers asked respondents was, "When negotiating do you hold fast to your objectives?" The researchers compiled the following results from the questionnaire and descriptive statistics. The answers in the questionnaire included "A," "B," "C," "D," and "E." With "A" being Always and "E" being Rarely. Later, the answers were quantified on a scale of 1-5. The mean of question six was 3.895 with a standard deviation of 0.839 . This information can be found below in Table 1 . This indicates to researchers the majority rarely hold fast to their objectives while negotiating.

The next question that researchers looked at was question 13 on the questionnaire, "What do you do when you are in a negotiation and the other party will not give anything away?" The answers ranged from "A" 'feeling that you've reached a stalemate and give up,' to "E" 'ask questions and explore possibilities. The majority answered that they would ask questions and explore possibilities. According to Table 1 (below), the mean of question 13 is 3.77 with a standard deviation of 1.23.

"When do you raise important issues during a negotiation?" Answers could be "A," "B," "C," "D," or "E," with " $A$ " being 'early on in the negotiation' to "E" being 'towards the end of the negotiation.' As seen in Table 3 (below) the mean is 3.66 with a standard deviation of 1.19. This indicates that more people bring up important issues toward the end of the negotiation versus the beginning of a negotiation. 
TABLE 3

THE MEANS PROCEDURE

\begin{tabular}{lllllll}
\hline Variable & Label & $\mathbf{n}$ & Mean & Std Dev & Minimum & Maximum \\
\hline $\mathbf{1}$ & $\mathbf{1}$ & 96 & 3.45 & 1.24 & 1.00 & 5.00 \\
$\mathbf{2}$ & $\mathbf{2}$ & 96 & 2.78 & 1.30 & 1.00 & 5.00 \\
$\mathbf{3}$ & $\mathbf{3}$ & 96 & 3.00 & 1.41 & 1.00 & 5.00 \\
$\mathbf{4}$ & $\mathbf{4}$ & 96 & 3.46 & 1.58 & 1.00 & 5.00 \\
$\mathbf{6}$ & $\mathbf{6}$ & 96 & 3.90 & 0.84 & 2.00 & 5.00 \\
$\mathbf{7}$ & $\mathbf{7}$ & 96 & 3.53 & 1.22 & 1.00 & 5.00 \\
$\mathbf{8}$ & $\mathbf{8}$ & 96 & 3.24 & 1.24 & 1.00 & 5.00 \\
$\mathbf{9}$ & $\mathbf{9}$ & 96 & 3.45 & 1.07 & 1.00 & 5.00 \\
$\mathbf{1 0}$ & $\mathbf{1 0}$ & 96 & 2.79 & 1.31 & 1.00 & 5.00 \\
$\mathbf{1 1}$ & $\mathbf{1 1}$ & 96 & 3.66 & 0.97 & 1.00 & 5.00 \\
$\mathbf{1 2}$ & $\mathbf{1 2}$ & 96 & 4.33 & 0.98 & 1.00 & 5.00 \\
$\mathbf{1 3}$ & $\mathbf{1 3}$ & 96 & 3.77 & 1.23 & 1.00 & 5.00 \\
$\mathbf{1 4}$ & $\mathbf{1 4}$ & 96 & 3.32 & 1.11 & 1.00 & 5.00 \\
$\mathbf{1 5}$ & $\mathbf{1 5}$ & 96 & 3.67 & 1.19 & 1.00 & 5.00 \\
$\mathbf{1 6}$ & $\mathbf{1 6}$ & 96 & 2.72 & 1.40 & 1.00 & 5.00 \\
\hline
\end{tabular}

The Table above lists each question from the questionnaire. One can see the sample size is $n=96$. The Table also shows the average answer and the standard deviation of each question on the questionnaire. These are represented in their respective columns, Mean and Std Dev. Last, the table shows the minimum and maximum of each question. All answers "A," "B," "C," "D," and "E" were quantified 1-5 respectively.

\section{CONCLUSIONS}

Research shows millennials act on impulse or for instant gratification. What causes the lack of interest for millennials to negotiate, is it from embarrassment, lack of knowledge, lack of want, or is it another factor? Why are millennials unwilling to negotiate? This is a significant issue because negotiation is how employees increase their salary and reduce prices on larger items such as cars. Generations before millennials negotiated with ease and would fight to get their way, but Millennials do not follow in those footsteps. The main question is why has it changed and what is causing this generation to be unwilling to negotiate when it could better themselves.

Are millennials unwilling to negotiate their salaries? As stated before, this research is important because the percentage of millennial employees in this country is growing. Millennials need to start negotiating for better salaries and benefits before losing the opportunity to do so.

First, the research shows millennials do know how a negotiation should go, according to the questionnaire, meaning they have the skills to negotiate. This connects back to buying condoms because when it comes to buying condoms people know what the consequences are when they are not used, yet people still choose often not to buy and use them. This is the same idea as with negotiating. From the 
research done, the data shows over seventy-seven students scored above fifty, which shows they have the skills to negotiate. Millennials are still hesitant about negotiation said by most employers. This plays into the fact millennials have the same human behavior of instant gratification as others and often do not think about the future on decisions. Their focus tends to be on short-term comfort rather than waiting for something desired. This can cause them to be lowballed by employers without them even knowing it.

This data shows males are typically more aggressive than females and when it comes to negotiating. The reason is males often are less willing to accept manipulation by salespeople. From the data, researchers show males are often more conditioned to require a higher salary to "be the breadwinner." On the other side, females can also be aggressive but can be easily taken advantage of when it comes to negotiation if they aren't aware of how to negotiate.

Second, this research shows the students, and millennials as a whole, do not need to be taught how to negotiate, but rather how and when to apply the knowledge. They also need to develop comfort in negotiating. This can be seen in the research by Yanessa, Dunn, Yansick, \& Jordan on condom purchases and Layng on negotiation. Many Millennials do not understand how to negotiate so employers can do what they want when it comes to giving starting salaries. Once millennials learn how to apply the knowledge they have it will show a great benefit to the generation and it could also decrease the number of millennials who do not negotiate. Learning how to negotiate is similar to learning how to interview because once the basic knowledge is learned, and the person is taught how to apply that knowledge, it only takes practice and experience to master the craft.

Third, for the students who answered question seventeen, organizing a class for these students so they can improve their skills and understanding of what negotiating is. Then they can be better prepared for the business world because all the students who took this questionnaire are students who will be joining the workforce in the coming years. This can apply to other millennials who are on the other end of the age scale and who are already in the workforce but still may not have these skills.

\section{Implications for Management}

The research from this study has several benefits. First, this research increases understanding of the millennial generation in the business aspect. It explored why millennials don't negotiate and their behavior. By understanding millennial's behavior and why they don't negotiate gives researchers insight on how to improve understanding.

Second, this research helps to have a better understanding of millennials' negotiation skills and how they can improve. Researchers found that millennials know what negotiation is just need help in acquiring the knowledge on how and when to negotiate. Researchers also found that millennials needed to increase their willingness to negotiate their salaries. Participants indicated that adding a salary negotiation class would improve their skills and understanding of negotiations and would better prepare them for the business world.

Lastly, this information can be used to benefit the upcoming workforce and the generation after the millennials. By incorporating salary negotiation earlier, students will have the knowledge needed on how and when to negotiate. Early exposure in classes or through workshops will also increase comfort and confidence in one's negotiating skills

\section{Research Limitations}

During the process of this paper, there were many limitations. The first limit was the sample size, though it met the criteria for normal distribution, $n=30$, a larger sample size would have been desired. The next limitation was the amount of diversity within the school. If possible, the next time this research is done, a poll of the whole school with every department would be more telling. Also, the poll's length was reduced because teachers had limited time to let students complete the polls during class time. Lastly, the survey did not include any qualitative questions that could have helped develop strategies to encourage negotiation or allow ample opportunity for the sample population to identify other insight not identified in the survey. 


\section{Future Research}

This study can lead to several possible future research opportunities and should proceed full steam ahead. First, the research could be done on the generation before or after millennials to test for differences between generations. Next, this information could be used to determine prices millennials place on cars, and other products for which negotiation skills are used, to decide if either generation tends to pay full price or less from negotiation. Lastly, this data could then be used to put plans in place to get the millennials into classes that will help them learn when the proper time to negotiate is, and how to apply the knowledge so they can stop embarrassment from happening to see if this changes the generational tendency.

\section{REFERENCES}

Bureau of Labor Statistics. (2017). Millennials and the pay gap: Monthly Labor Review. Retrieved from https://www.bls.gov/opub/mlr/2017/beyond-bls/millennials-and-the-pay-gap.htm

Colao, J. (2012, October 11). Welcome to the new millennial economy: Goodbye ownership, hello access. Forbes. Retrieved from https://www.forbes.com/sites /jjcolao/2012/10/11/welcome-to-the-newmillennial-economy-goodbye-ownership-hello-access/\#361797f374ab

Cook, S. (2007). Compendium of Questionnaires and Inventories (Volume 2). Gower Publishing Limited. Retrieved from https://sites.google.com/a/books-now.com/en597/978159996057988compcaGEglocal93

Dabol, P. (2011, January 12). Celebrities in advertising almost always a big waste of money. Adage. Retrieved from https://adage.com/article/cmo-strategy/celebrities-ads-lead-greater-sales/148174/

Deal, J. (2017, May 17). Millennials aren't impatient. They're prudent. Retrieved from https://blogs.wsj.com/experts/2017/05/16/millenials-arent-impatient-theyre-prudent/

Forer, L. (2017, September 26). An inside look at the habits of millennial shoppers [Infographic]. MarketingProfs. Retrieved from https:/www.marketingprofs.com/chirp/2017/32824/an-Insidelook-at-the-habits-of-millennial-shoppers-infographic

Goudreau, J. (2014, June 23). Failing to negotiate your first salary could cost you half a million dollars. Business Insider. Retrieved from https://www.businessinsider.com/millennials-and-negotiatingsalaries-2014-6

Groth, B.I. (2001). Brit trips-midway hotel: A simulated negotiation. Business Communication Quarterly, 64(1), 63-78. ISSN: 1080-5699. Retrieved from https://eric.ed.gov/?id=ej621188

Jacobsen, W.C., \& Forste, R. (2010). The wired generation: Academic and social outcomes of electronic media use among university students. Cyberpsychology, Behavior, and Social Networking, 4(5), 275-280. https://doi.org/10.1089/cyber.2010.0135

Jones, S., Johnson-Yale, C., Millermaier, S., \& Perez, F. (2009). Everyday life, online: U.S. college students' use of the internet. First Monday, 14(10), 5. Retrieved from http://bigthink.com/ideafeed/why-we-act-against-our-own-best-interest

Kestenbaum, R. (2017, June 14). This is how millennials shop. Forbes. Retrieved from https://www.forbes.com/sites/richardkestenbaum/2017/06/14/this-is-how-millennialsshop/\#18004626244c

Khazan, O. (2017, January 6). Women know when negotiating isn't worth it. The Atlantic. Retrieved from https://www.theatlantic.com/business/archive/2017/01/women-negotiating/512174/

Layng, J.M. (2009, July 6). Consulting on negotiation: Teaching business students basic techniques. Business and Professional Communication Quarterly, 72(3), 341-344. https://doi.org/10.1177/1080569909340628

Levine, L. (2011). Eliciting cooperation with communication: Negotiating with the millennial generation. Social Science Research Network. https://doi.org/10.2139/ssrn.1872652

Liu, J.T., Serapio, M., Zhu, Y., \& Cavusgil, S. (2019). The new generation of millennial entrepreneurs: A review and call for research. International Business Review, 28(5), 1-10. https://doi.org/10.1016/j.ibusrev.2019.05.001 
Lockert, M. (2017, May 3). Why aren't millennials negotiating for higher salaries? Chime. Retrieved from https://www.chimebank.com/2017/05/03/why-arent-millennials-negotiating-for-higher-salaries/

McGinnis Johnson, J., \& Ng, E. (2016). Money Talks or Millennials Walk. Review of Public Personnel Administration, 36(3), 283-305. https://doi.org/10.1177/0734371X15587980

Myers, K.K., \& Sadaghiani, K. (2010, March 05). Millennials in the workplace: A communication perspective on millennials' organizational relationships and performance. Journal of Business and Psychology, 25(2), 225-238. https://doi.org/10.1007/s10869-010-9172-7

Pate, S.S., \& Adams, M. (2013). The influence of social networking sites on buying behaviors of millennials. Atlantic Marketing Journal, 2(1), 91-108. ISSN: 2165-3879

Pöyry, E., Parvinen, P., \& Malmivaara, T. (2013). Can we get from liking to buying? Behavioral differences in hedonic and utilitarian Facebook usage. Electronic Commerce Research and Applications, 12(4), 224-235. https://doi.org/10.1016/j.elerap.2013.01.003

Radcliffe, B. (2018, January 29). Millennials: Finances, investing, \& retirement. Investopedia. Retrieved from https://www.investopedia.com/terms/m/millennial.asp

Schwartz, T. (2014, July 23). Why don't we act in our own best interest? Retrieved from https://hbr.org/2012/01/why-dont-we-act-in-our-own-bes.html

Stein, J. (2013, May 20). Millennials: The me me me generation. Time Magazine, 14-20. Retrieved from $\mathrm{http}: / /$ time.com/247/millennials-the-me-me-me-generation/

Sweeney, R. (2006). Millennial behaviors and demographics. New Jersey Institute of Technology, Newark, NJ. Retrieved from https://unbtlsca/teachingtips/pdfs/sew/millennial-behaviors.pdf

United States. Congress. Joint Economic Committee. (2016). Millennial voices on advancing the American Dream: Hearing before the Joint Economic Committee, Congress of the United States, One Hundred Fourteenth Congress, first session, November 18, 2015. (United States. Congress. Senate. S. (114-176).

Yannessa, J.F., Dunn, M.S., Yansick, K., \& Jordan, D. (2017). Millennial student embarrassment toward condom purchase/acquisition. American Journal of Health Studies, 32(3), 171-176. https://doi.org/10.1016/j.adolescence.2008.01.002

\section{APPENDIX A}

\section{Copy of the Survey Administered}

Negotiation Questionnaire

You are given two statements in answer to each question. Circle the letter which is most representative of your feelings, where:

$\mathrm{A}$ and $\mathrm{E}$ are closest to the different statements

$\mathrm{B}$ and $\mathrm{D}$ less close but still reflect your feelings

$\mathrm{C}$ is the middle between the two statements.

Answer each question as quickly and honestly as you can.

If you have negotiated please fill out the following questions. If you have never negotiated, please skip to question 17.

1. To what extent do you prepare before a negotiation?
To a great extent
A B C D E
To a little extent

2. To what do you pay most attention when preparing for a negotiation? The other party's A B C D E The other party's strengths weaknesses

3. How do you regard the process of negotiating?
One party wins
A B C D E
Both parties win the other loses 
4. What should be the outcome of a negotiation?

A good result $\quad$ A B C D E

A good result for both parties for your organization

5. Do you set clear objectives for a negotiation?
Always
A B C D E
Rarely

6. When negotiating do you hold fast to your objectives?
Always
A B C D E
Rarely

7. How often do you become impatient or lose your temper in a negotiation?
To a great extent
A B C D E
To a little extent

8. Which do you do more of in a negotiation?
Talk
A B C D E
Listen

9. What do you feel about making concessions in a negotiation?
Don't make
A B C D E
Recognize the principles concessions
of giving and getting

10. How do you test assumptions in a negotiation?

Wait to hear what the A B C D E

other party has to say

Use open questions to test

assumptions

11. As you work to reach agreement, who usually sums up what has been agreed along the way? You

A B C D E The other party

12. What do you do when you are in a negotiation and you don't understand something?
Ask questions to pass
A B C D E
Let the matter without saying
clarify the matter
anything

13. What do you do when you are in a negotiation and the other party will not give anything away?

Feel that you've reached A B C D E Ask questions and explore possibilities

stalemate and give up

14. How do you make concessions during a negotiation?

Make the concession early A B C D E

on in the negotiation

Make the concession slowly and make it

look more significant than it is

15. When do you raise important issues during a negotiation?

Early on in the negotiation A B C D E

Towards the end of the negotiation

16. With whom do you feel happier negotiating?

Someone on the same level A B C D E

Anyone, irrespective, of title or position as you

17. Why don't you choose to negotiate?
Embarrassment
Lack of knowledge how
Lack of want
Other 
If Other:

Student information:

Class Standing: Freshmen Sophomore Junior Senior Refusal To Answer

Major:

Refusal To Answer

Age:

Gender:

Male

Female

Refusal To Answer

Ethnicity:

Refuse To Answer

Country:

Refusal To Answer

State:

Refusal To Answer

Refusal To Answer

\section{APPENDIX B}

Negotiation Questionnaire Survey Scoring

\begin{tabular}{llllll}
\hline Question & A & B & C & D & E \\
\hline 1 & 5 & 4 & 3 & 2 & 1 \\
2 & 5 & 4 & 3 & 2 & 1 \\
3 & 5 & 4 & 3 & 2 & 1 \\
4 & 1 & 2 & 3 & 4 & 5 \\
5 & 1 & 2 & 3 & 4 & 5 \\
6 & 5 & 4 & 2 & 2 & 1 \\
7 & 3 & 4 & 5 & 2 & 1 \\
8 & 1 & 2 & 3 & 4 & 5 \\
9 & 1 & 2 & 3 & 4 & 5 \\
10 & 1 & 2 & 3 & 4 & 5 \\
11 & 1 & 2 & 3 & 4 & 5 \\
12 & 5 & 4 & 3 & 2 & 1 \\
13 & 5 & 4 & 3 & 2 & 1 \\
14 & 5 & 4 & 3 & 2 & 1 \\
15 & 1 & 2 & 3 & 4 & 5 \\
16 & 1 & 2 & 3 & 4 & 5 \\
17 & 1 & 2 & 3 & 4 & 5 \\
18 & 5 & 4 & 3 & 4 & 5 \\
19 & 1 & 2 & 3 & 2 & 1 \\
20 & 5 & 4 & & & \\
\hline Total & & & & \\
\hline
\end{tabular}

